\author{
Hapiz Islamsyah \\ Fakultas Industri Kreatif dan Telematika \\ Universitas Trilogi \\ hapiz@gmail.com
}

\title{
PERANAN STYLING DAN ERGONOMI PADA CITY CAR TERHADAP MASYARAKAT URBAN JAKARTA (STUDI KASUS EKSTERIOR DAN INTERIOR SUZUKI KARIMUN WAGON R DAN DAIHATSU AYLA)
}

\begin{abstract}
Abstrak. Ketika kita berbicara tentang desain sangat berkaitan dengan banyak aspek, hal yang paling penting dari aspek ini adalah fungsi dan estetika, desain tanpa estetika menjadi kekosongan dan desain tanpa fungsi menjadi tidak berguna. Saai ini ilmu pengetahuan, teknologi dan budaya hari ini menjadi bagian gaya hidup. Sebagian besar objek yang digunakan oleh manusia, dirancang oleh desainer, untuk memenuhi kebutuhan dasar dan keinginan manusia, gaya hidup manusia modern adalah kebanggaan paling penting, alat elektronik dan otomotif yang sebagian besar terhubung dengan kehidupan mereka. Dalam penelitian ini dibahas tentang kinerja LCGC (Low Cost Green Car) yang paling umum digunakan masyarakat urban di Jakarta dengan melihat dari segi styling dan ergonomis, penelitian ini dimulai dengan mengumpulkan data melalui observasi dan wawancara dari resoponden dan ahli. Semua data akan diolah dan hasil dari penelitian ini adalah untuk mendorong industri manukfaktur dan desainer produk otomotif untuk membuat mobil dengan aspek estetika dan aspek ergomonik yang sangat penting.
\end{abstract}

Kata kunci: gaya hidup, fungsi, ergonomis, styling, LCGC

\begin{abstract}
When we talk about Design is related to many aspect, the most important things of this aspect is functions and aesthetic, design witout aesthetic becomes emptiness adnd design without function becomes useless. Now day's science, technology and culture become part of life style. Most of object that is used by human, is designed by designer, to fill basic needs and desire of humanity, modern human lifestyle is the most essential pride, automotive electrical goods mostly connected to their life. In this research talk about performance of LCGC (Low Cost Green Car) the most common used from urban society in Jakarta whit looking from styling and ergonomic aspect, this research begins with collecting data through observation and interviews from resoponden and the expert. Moreover all data will be processed and the result of this research is to push automotive manufacture and product designer to build a car with more aesthetic aspect and ergomonic aspect it's very important.
\end{abstract}

Keywords: lifestyle, functions, ergonomic, styling, LCGC

\section{Pendahuluan}

\subsection{Latar Belakang Masalah}

Transpotasi menjadi hal mendasar dalam masyarakat urban khususnya di daerah Ibu Kota. Pergerakan manusia di kota Jakarta berlangsung hampir 24 jam dalam sehari membuat peran transpotasi sangat penting, jumlah jalan di Jakarta yang hampir tidak bertambah tiap tahunnya membuat kemacetan semakin parah, moda transpotasi umum yang ada dikota ini ( Jakarta ) kurang mendukung baik dari segi keamanan dan kenyamanan.

Konsep city car sendiri adalah sebagai sarana transpotasi di kota besar dan kota urban. Terlepas dari konsep awal kota Jakarta sudah tidak layak untuk dikendarai secara nyaman pada jam jam sibuk antara lain pukul 05:00 sampai pukul 12:00 dan sore hari pukul 17:00 sampai pukul 20:00 


\subsection{Pembatasan Masalah}

Pembatasan masalah pada penelitan ini di titik beratkan kepada desain kendaraan LCGC (Low Cost Green Car) atau kendaraan murah dan ramah lingkungan. Dilihat dari segi: a.Styling b. ergonomi pengguna dan keamanan pengguna c. dampak terhadap gaya hidup.

Dari sudut pandang desainer masalah utama dalam city car adalah tingkat kenyamanan pengguna, apakah city car kelas LCGC sudah menerapkan standar kelayakan ergonomi penggunanya. Bila di telaah lebih dalam maka akan di dapat hubungan antara tingkat kenyamanan dengan harga yang murah,dengan menggunakan material yang murah apakah mempengaruhi keamanan dan kenyamanan penggunanya.

\subsection{Rumusan Masalah}

Dari hasil identifikasi dan batasan masalah diatas serta mempertimbangkan bidang keilmuan penulis, maka masalah dalam penelitian ini di fokuskan kepada :

1.Bagaimana mempertahankan styling pada city car tanpa mengorbankan segi ergonomi?

2. Bagaimana pengaruh city car terhadap gaya hidup masyarakat urban?

Kota Jakarta adalah kota dengan penduduk yang sangat padat oleh karena itu peran city car dalam perkembangan kota Jakarta sangat penting. Oleh karena itu maka tingkat kemanan dan kenyamana dari sebuah city car harus sesuai dengan karakter masyarakat kota Jakarta.

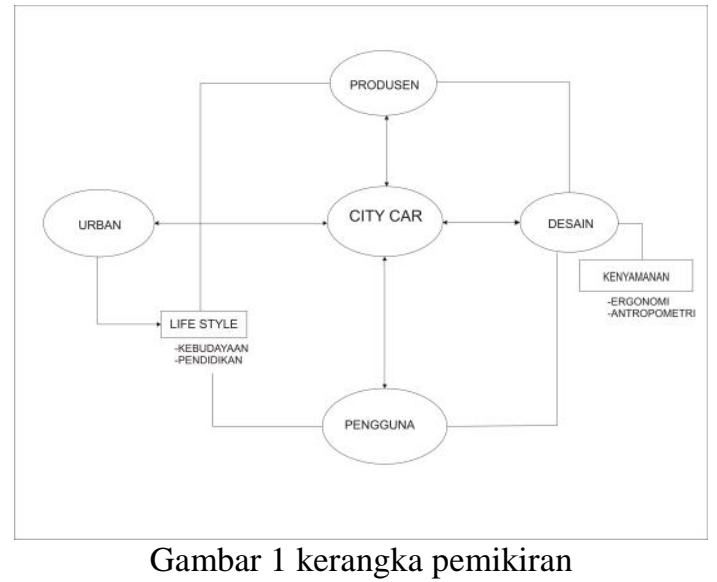

\section{METODE PENELITIAN}

Untuk memehami dan mengungkap permasalahan dalam penelitian ini maka jenois penelitian yang digunakan adalah penelitian lapangan dengan metode penelitian kualitatif yang bersifat deskriptif. Metode yang digunakan untuk meneliti hubungan keamanan dan kenyamanan suatu desain, suatu kondisi life style atau gaya hidup masyarakat urban di perkotaan khususnya di Jakarta. 
Menjawab permasalahan yang dikemukakan dalam penelitian ini kajian yang digunakan adalah tentang teori virtuvius, ergomoni dan gaya hidup. Dalam teori virtuvius dapat dilihat bahwa hubungan antara fungsi dan keindahan menjadi satu kesatuan dalan desain

\author{
Utilitas ... Firmitas ... Venustas \\ Kesediaan ... Kekakuan ... Kesenangan \\ Utilitas ... Struktur ... Ketertarikan \\ Guna ... Konstruksi ... Tampilan \\ Fungsi ... Teknologi ... Keindahan
}

Terapan teori virtuvius

- utylitas :

kebutuhan

fungsi

denah

- firmitas :

utama

struktur

potongan

- venustas :

seni

keindahan

\title{
3. City car dari masa ke masa
}

Perkembangan city car dari masa ke masa dapat dilihat dari beberapa perubahan mendasar antara lain desain (styling), material, dan dimensi. Perkembangan desain city car paling cepat berubah di belahan asia dimana pasar Asia di kuasai oleh pabrikan Jepang, Jepang mampu menguasai pasar asia dengan city car karena faktor antopometri dimana Jepang juga merupakan kawasan asia, keberhasilan jepang dalam membuat city car juga di dukung oleh perkembangan teknologi yang sederhana namun efisien yang sangat cocok dengan karakter masyarakat asia. 


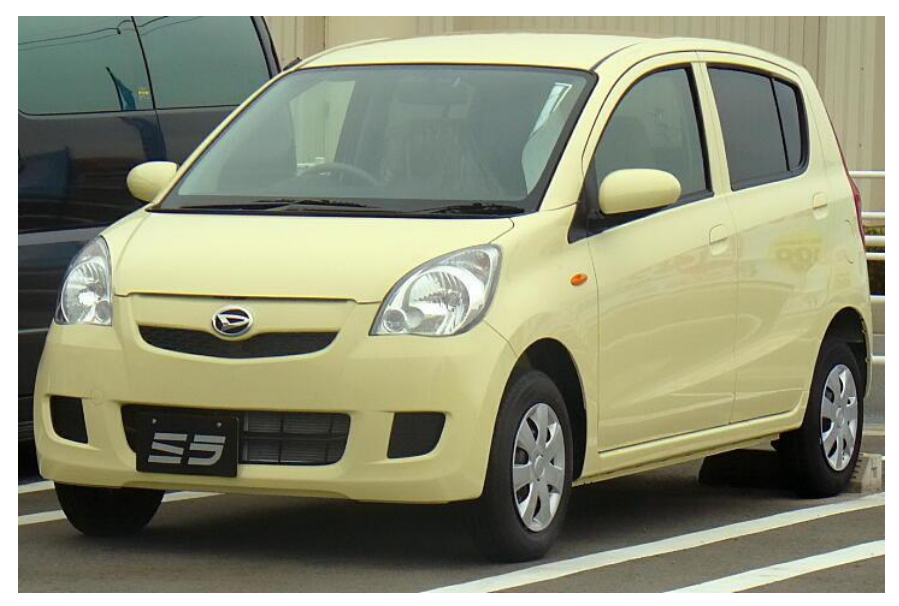

Gambar 2 city car

Pabrikan asal eropa dan beberapa pabrikan asal Amerika juga menelurkan city car umumnya, pabrikan eropa lebih banyak menbuat varian city car.

seiring perkembangan keilmuan di bidang desain maka bentuk dan styling dari city car mulai di perhitungkan dalam segi gaya hidup, city car identik dengan masyarakat urban yang mandiri, dinamis dan individu. Di karenakan faktor kemandiriian maka desain city car menjadi icon sebagai masyarakat yang mandiri dengan kelas sosial menengah.

City car pada objek penelitian tidak terlepas dari unsur estetik, simbol sosial psikologi dan teknologi. City car yang pada awalnya hanya sebagai kendaraan yang didesain karena keterbatasan bahan baku hingga saat ini berubah menjadi gaya hidup modern. Dalam masyarakat modern standar perilaku kehidupan seolah sudah dipatenkan dalam aturan tertulis sehingga masyarakat modern cenderung mengutamakan citra dan simbol dalam berkehidupan, salah satu simbol kesuksesan masyarakat modern adalah materi. Stigma masyarakat yang melihat bahwa kendaraaan roda empat lebih tinggi derajatnya dari pada kendaraan roda dua terjadi di masayarakat urban di Jakarta, dengan peraturan yang dibuat oleh penguasa juga mempertegas stigma ini, sebagai contoh parkir kendaraan roda empat lebih mudah dijangkau di pusat-pusat perbelanjaan dan perkantoran, sehingga citra kendaraan roda empat seolah-olah lebih tinggi. Hal tersebut dimanfaatkan oleh para produsen mobil untuk mengambil pasar masyarakat kelas menengah untuk merasakan secara parsial fasilitas yang ditawarkan oleh masyarakat kelas atas.

Dengan mendesain mobil murah yang ramah lingkungan diharapkan banyak dari kalangan menegah untuk membeli mobil ini. City car bukan hal baru dalam industri otomotif sehingga city car juga tidak didesain secara asal tetapi melewati tahapantahapan desain yang ketat. Dalam penelitian ini pasar kalangan menengah sangat sulit untuk dipahami di satu sisi mereka menginginkan harga murah tetapi disisi lainnya mereka menginginkan sesuatu yang mewah dalam sekaligus.

Ketika sebuah desain akan dirancang dan setelah dirancang faktor kepratisan dalam penggunaanya harus diperhatiakan dalam masyakat modern selain kepraktisan juga harus ada nilai estetik. 


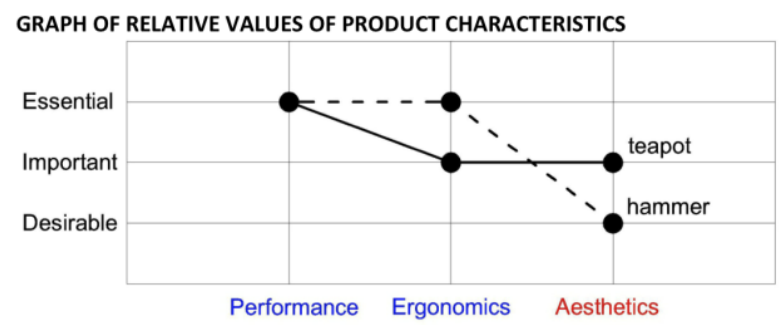

Gambar 3 hubungan antara sebuah nilai dan kegunaan dalam sebuah benda

Sebuah city car harus memiliki unsur estetik, ergononi yang cukup karena sebuah kendaraan harus diciptakan aman bagi pengguna maupun orang lain yang tidak menggunakan, faktor keamaanan dan kenyamanan menjadi kunci kesuksesan kendaraan pada masa kini dimana manusia sebagai bio physics memiliki ketakutan-ketakutan akan fisiknya.

Ketika berbicara faktor ergonomi maka tidak terlepas dari faktor keamanan, ketika faktor keamanan terpenuhi maka faktor kenyamanan secara psikologis terpenuhi, tetapi tidak sampai disitu saja faktor kenyamanan akan terpenuhi secara fisik.

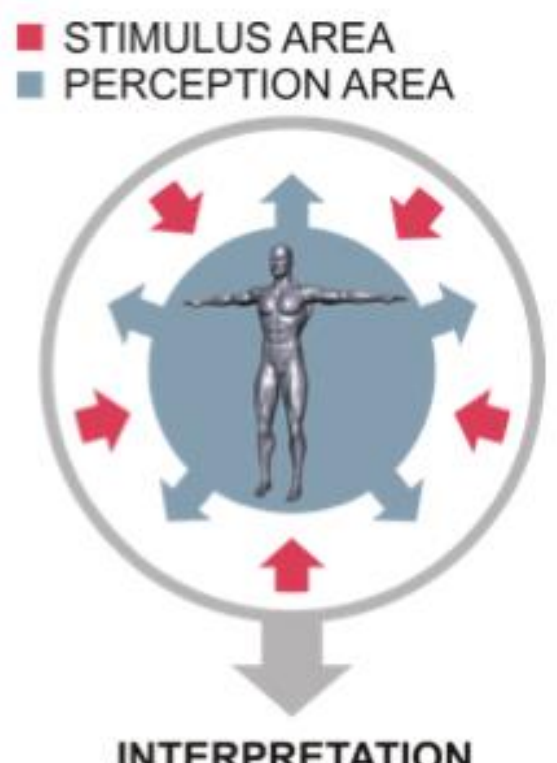

\section{INTERPRETATION}

\section{RESPONSE}

Gambar 4 reaksi manusia terhadap benda desan dan lingkungan

(sumber Ahadiat)

Karena manusia bersifat bio physics, maka semua panca indra yang ada dalam tubuh manusia bereaksi terhadap benda desain karena benda desain memberikan rangsangan terhadap panca indara. Bila melihat hal tersebut sebuah city car di desain harus mengikuti aturan keamanan dan kenyamanan. 


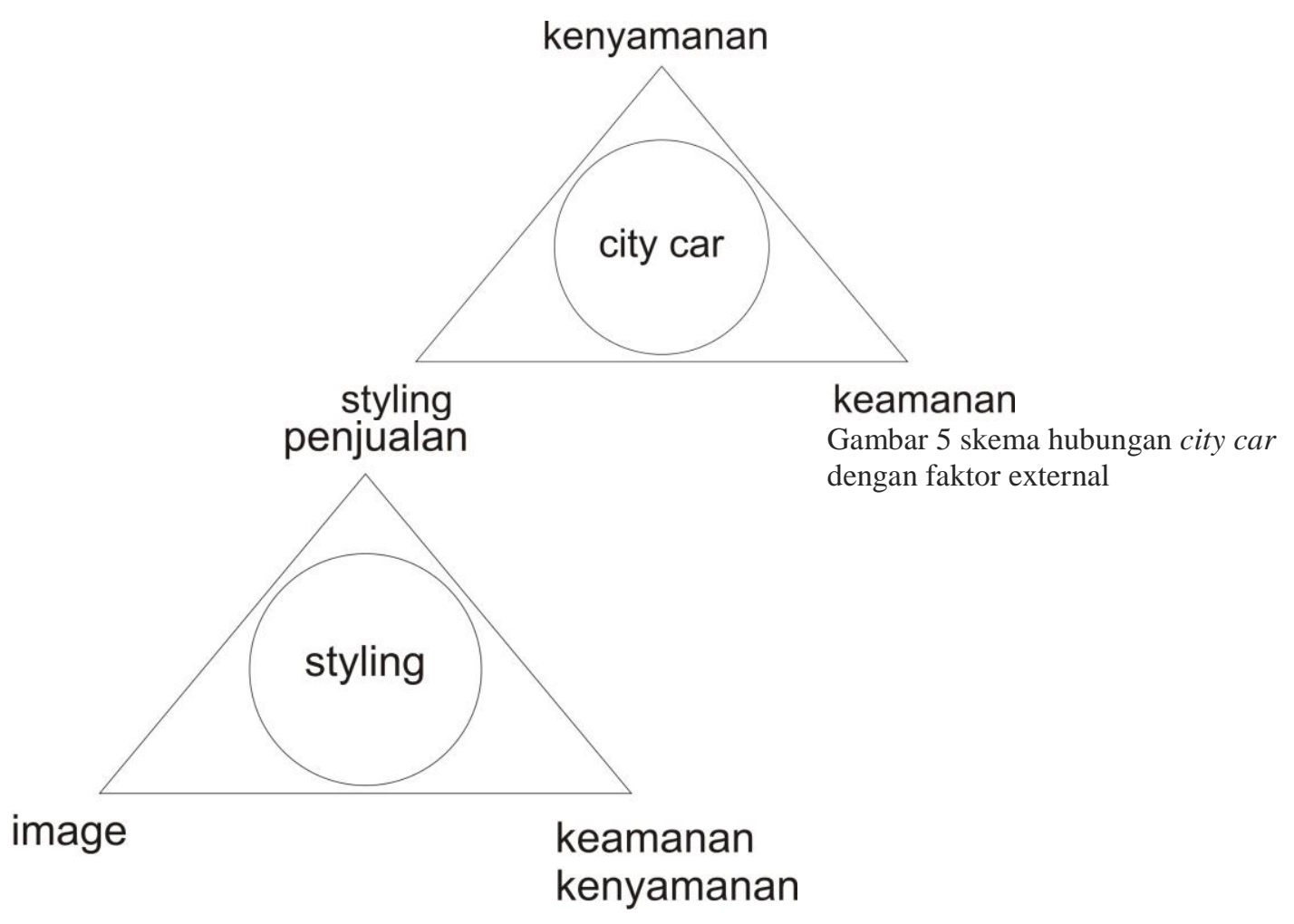

perkembangan gaya hidup dikota besar terutama di Jakarta mempengaruhi cara pandang masyarakatnya melihat citra, sehingga citra dalam masyarakat menjadi hal penting dalam memenuhi kehidupan, skema dibawah menjelaskan arah perkembangan gaya hidup.

PERKEMBANGAN GAYA HIDUP

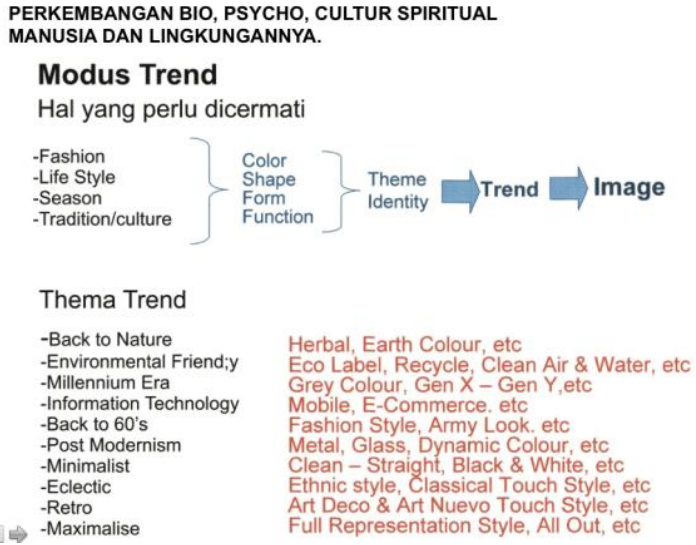

Gambar 6 skema penggambaran gaya hidup terhadap lingkungan (sumber Ahadiat 2012)

City car tidak terlepas dari gaya hidup ketika kita berbicara gaya hidup maka styling design sangat berperan dalam faktor ini mempengaruhi penjualan pada jenis kendaraan ini oleh karena itu divisi styling desain pada perusahaan otomotif tidak mau melepas pasar city car. 


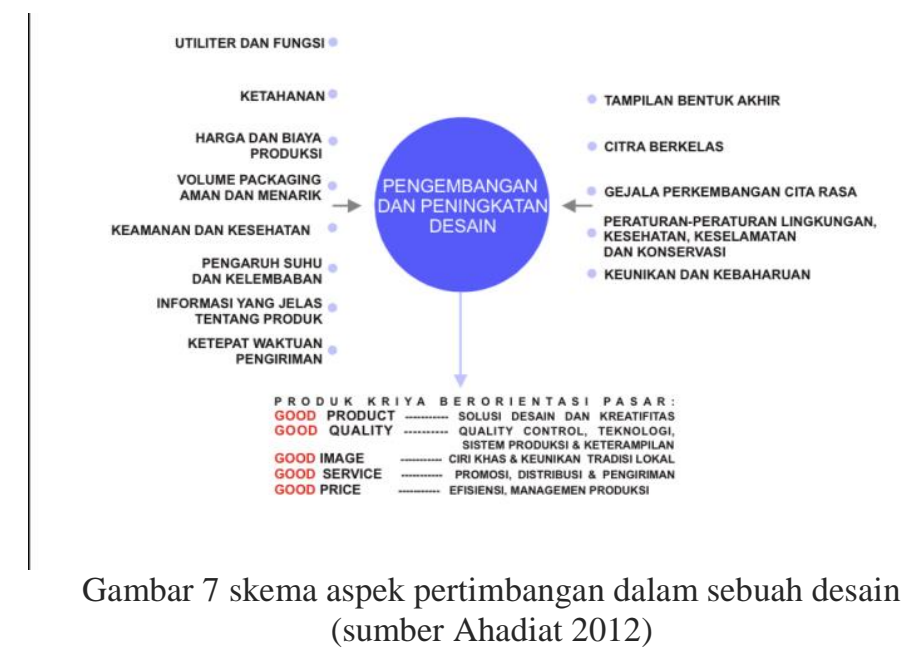

dapat dilihat bahwa penjualan city car di Indonesia cukup mempunyai tempat yakni menguasai $18 \%$ dari total penjualan mobil.

\title{
4. HASILDAN ANALISA
}

City car yang lebih dikenal oleh masyarakat urban sebagai mobil dengan kapasitas dan dimensi yang kecil, seperti yang sudah dibahas di bab sebelumnya bahwa perkembangan city car dari tahun ketahun selalu mengalami perbaikan baik dari segi teknologi mesin, teknologi perakitan, teknologi material.

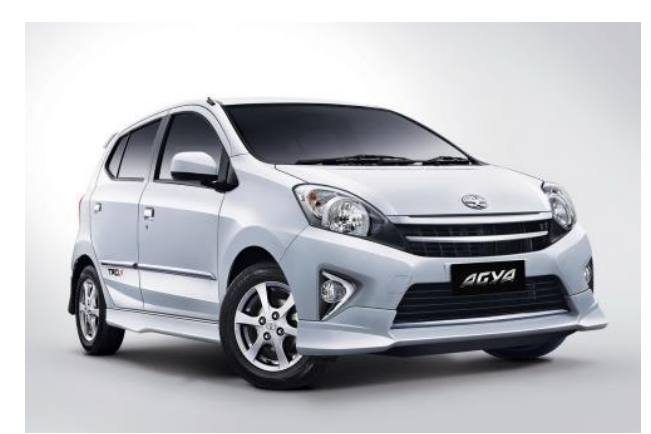

\author{
Gambar 8 city car keluaran tahun 2014 Toyota Agya \\ (sumber Fliker diakses pada tanggal 15 mei 2015 pukul 00:15 wib)
}

Seiring perkembangan teknologi dan kebudayaan manusia keberadaan city car cukup dipertimbangakan sebagai kendaraan yang cukup praktis efisien dan murah membuat city car diminati. Pada awal perakitan dan perancangan sebuah kendaraan memakan waktu yang amat panjang di butuhkan waktu dalam peyempurnaan sebuah purwarupa.

City car yang paling banyak beredar di Indonesia kelas LCGC (2014)
1. Toyota Agya
2. Daihatsu Ayla
3. Suzuki karimun
4. Honda Brio 


\section{Datsun GO}

objek penelitan difokuskan pada Daihatsu Ayla dan Suzuki Karimun hal ini didasari oleh nama besar Suzuki Karimun yang pada awalnya masuk dalam kelas city car menengah tapi ikut bertarung dalam kelas LCGC, dan pemilihan Daihatsu Ayla karena model Ayla dan Agya yang identik dan dari data dilapangan dapat dilihat bahwa peringkat minat terhadap merk Daihatsu dan Suzuki lebih tinggi dari Honda dan Datsun.

Suzuki dan Daihatsu menempati urutan LCGC yang cukup diminati dipasaran.

1. Suzuki karimun

Suzuki karimun hadir di Indonesia sejak tahun 1999 awal masuk di Indonesia Suzuki karimun mengusung platform Suzuki Wagon R di Jepang dan menggunakan desain tersebut ke seluruh dunia, Suzuki wagon R atau Suzuki karimun termasuk kategori city car (kei car).

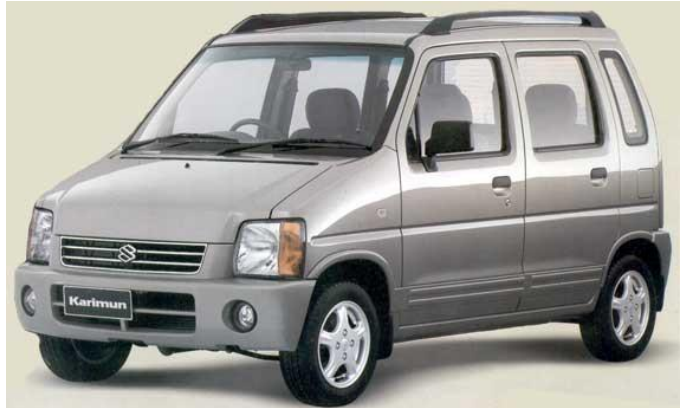

Gambar 9 Suzuki Karimun versi awal di Indonesia (sumber Google diakses 2015)

Pada tahun 2007 Suzuki karimun Indonesia memasukan versi karimun estilo yang di Jepang sendiri platform mobil ini digunakan oleh Nissan moco dan di India digunakan merk Maruti Zen estilo. Pada era Suzuki Karimun Estilo kurang diminati.

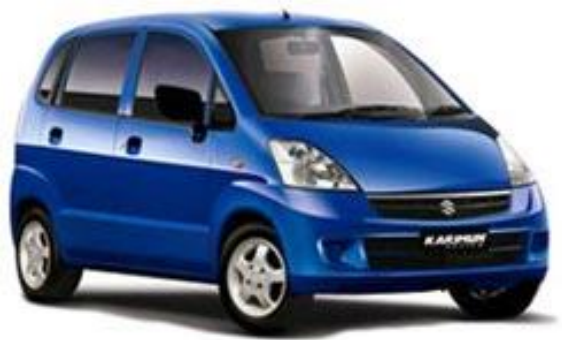

Gambar 10 Suzuki karimun estilo (sumber Pinterest diakses tahun 2015)

Tahun 2012 dicanangkang program mobil LCGC di Indonesia maka pabrikan Suzuki turut serta dalam program LCGC tersebut dengan menurunkan Suzuki Karimun Wagon R kembali, akan tetapi dengan spesifikasi LCGC 


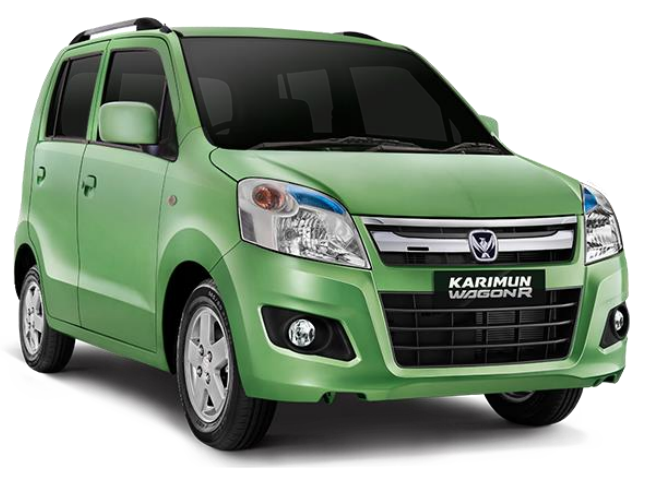

Gambar 11 Suzuki Wagon R (sumber Pinterest diakses pada tahun 2015)

Program pemerintah untuk LCGC adalah untuk mengatasi krisis minyak bumi dan memingkatkan unsur lokal dalam manufaktur otomotif, sehingga harga kendaraan dapat ditekan.

2. Daihatsu Ayla

Daihatsu pabrikan spesialis mobil kecil dan city car juga memasuki pasar LCGC di Indonesia dengan mengusung Daihatsu Ayla bersama saudara kembarnya Toyota Agya. Diperkenalkan di Indonesia tahun 2012, Daihatsu Ayla didesain oleh Astra Daihatsu Indonesia lahir karena melihat celah pasar LCGC dan program pemerintah yang mengharuskan pabrikan otomotif harus ikut dalam program LCGC.
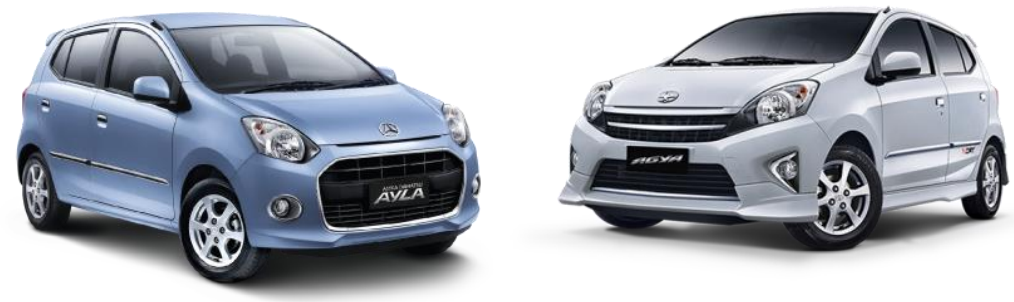

Gambar 12 Daihatsu Ayla dan Toyota Agya (sumber Flicker diakses pada tahun 2015)

\section{Komparasi antara Suzuki karimun Wagon R dan Daihatsu Ayla}

\begin{tabular}{|c|c|c|}
\hline Spesifikasi & Ayla & Karimun Wagon $\mathrm{R}$ \\
\hline Dimensi PxLXT (mm) & $3.600 \times 1.600 \times 1.520$ & $3.600 \times 1.475 \times 1.670-1.700$ \\
\hline Wheelbase $(\mathrm{mm})$ & 2.45 & 2.4 \\
\hline Transmisi & $\begin{array}{l}\text { Manual 5-percepatan /otomatis 4- } \\
\text { percepatan }\end{array}$ & Manual 5-percepatan \\
\hline Mesin & $1.000 \mathrm{cc}, 3$ silinder inline $12 \mathrm{~V} \mathrm{DOHCF1}$ & $1.000 \mathrm{cc}, 3$ silinder \\
\hline Tenaga max & 65PS@6.000 rpm & 68PS@6.200 \\
\hline Torsi max & $86.3 \mathrm{Nm} @ 3.600 \mathrm{rpm}$ & $90 \mathrm{Nm} @ 3.500$ \\
\hline Rem & $\begin{array}{l}\text { Depan solid (MT); cakram (AT), belakang } \\
\text { drum }\end{array}$ & Depan cakram, belakang drum \\
\hline Ban & 175/65 R14 alloy (tipe E MT 155/80 R13) & $145 / 80$ R 13 \\
\hline Sistem Kemudi & Rack dan Pinion & RHD \\
\hline Airbag & Ada & Tidak \\
\hline Audio & Ada & Ada (kecuali tipe GA) \\
\hline$A C$ & Ada & Ada \\
\hline Efisiensi bahan bakar & $20 \mathrm{~km} /$ liter & $20 \mathrm{~km} /$ /iter \\
\hline Ground Clearance & $180 \mathrm{~mm}$ & $170 \mathrm{~mm}$ \\
\hline Harga OTR Jakarta & Rp99,9-120,75 juta & Rp 77-99 juta \\
\hline
\end{tabular}

Gambar 13 table spesifikasi teknis Suzuki karimun wagon R dan Daihatsu Ayla 


\section{Komparasi desain eksterior Daihatsu Ayla dan Suzuki Karimun Wagon R}

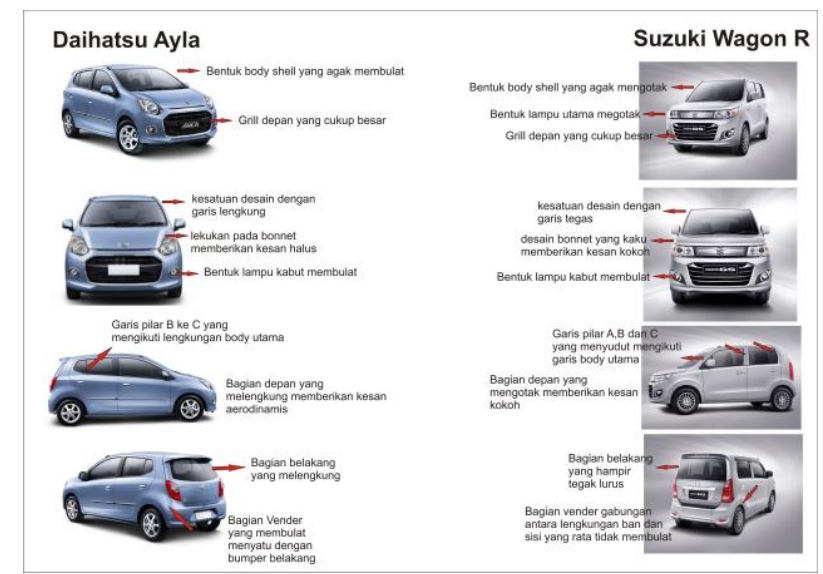

Gambar 14 Komparasi desain eksterior Ayla dan Karimun

Dari hasil pengamatan kedua objek penelitian pada desain Eksterior Daihatsu Ayla dan Suzuki Karimun maka terlihat perbaedaan yang mencolok pada kedua objek, dimana Daihatsu mengusung desain yang membulat lebih kearah Aerodinanis, sedangkan Suzuki Karimun mengusung desain yang mengotak (BOXXY), hal ini tidak terlepas dari concept car yang dimiliki oleh masing-masing pabrikan.

\section{Komparasi desain Interior antara Daihatsu Ayla dan Suzuki Karimun Wagon $\mathbf{R}$}

Perbandingan desain interior Suzuki Karimun Wagon $R$ dengan Daihatsu Ayla

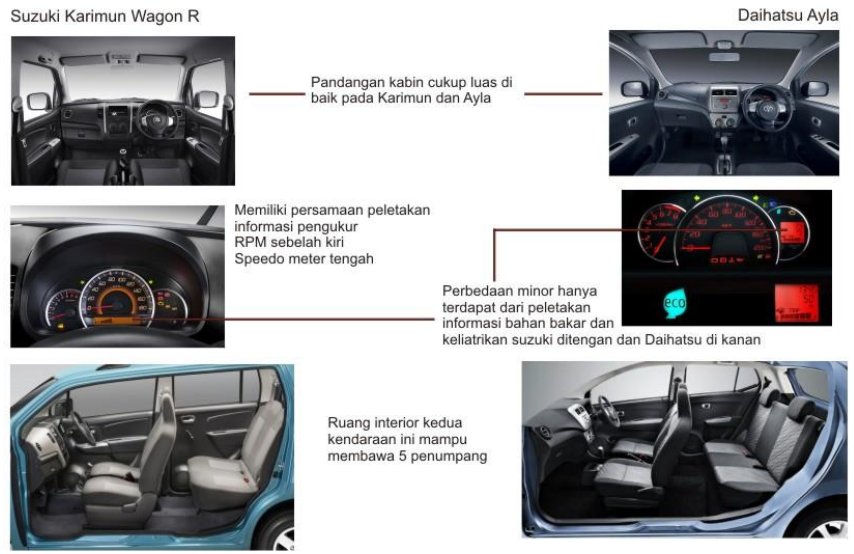

Gambar 15 Komparasi interior Karimun Wagon R dan Ayla

Dari kedua city car ini kabin interior cukup luas jarak pandang tidak ada blind spot yang menyulitkan pengendara, selain itu tampilan dashboard ada disebelah kanan dengan penyusunan tiga bagian utama, informasi putaran mesin, speedometer dan informasi kelistrikan kendaraan. Terdapat perbedaan minor pada peletakan sistem informasi kelistrikan, odometer dan bahan bakar pada kedua city car ini.untuk luasan kabin kurang lebih hampir sama karena mampu membawa 5 penumpang. 


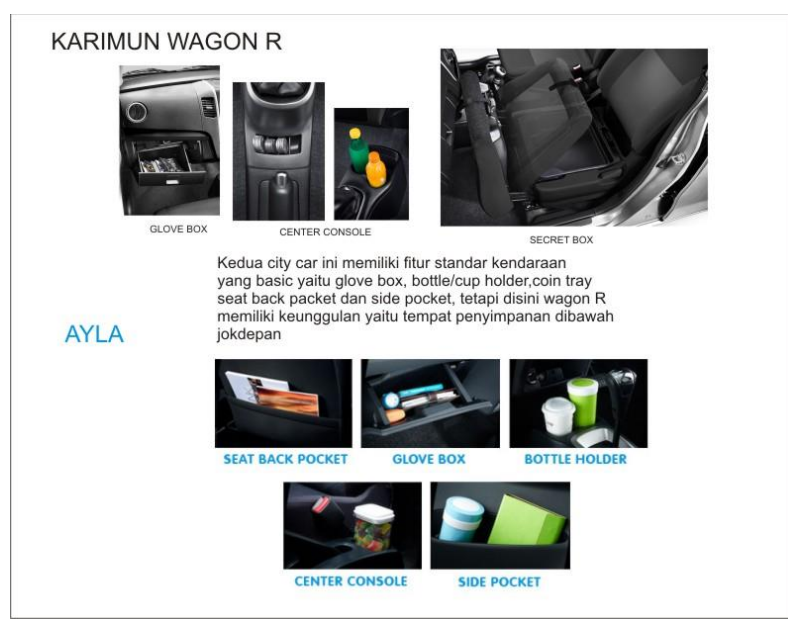

Gambar 16 kelengkapan standar interior Wagon R dan Ayla

pada kedua city car ini kelengkapan standar interior dimiliki oleh keduanya

- center console

- side pocket

- glove box

- seat back pocket

- bottle/cup holder

Suzuki wagon $\mathrm{R}$ memiliki fitur lebih yaitu wadah atau box dibawah jok penumpang, cukup berguna untuk manaruh dokumen penting agar tidak mencolok, tetapi fitur ini mengorbankan tingkat kenyamanan penumpang karena menipiskan busa jok penumpang, disisi lain jumlah bottle/cup holder pada Daihatsu Ayla lebih banyak, tetapi cup holder yang terletak dibagian depan center console dapat mengganggu tombol pendingin udara diarea dashboard.

Pengujian terhadap ergonomi interior kedua sampel ini dilakukan dengan cara mengujicobakan dan mensimulasikan kegiatan didalam kendaraan.

\section{Daihatsu Ayla}

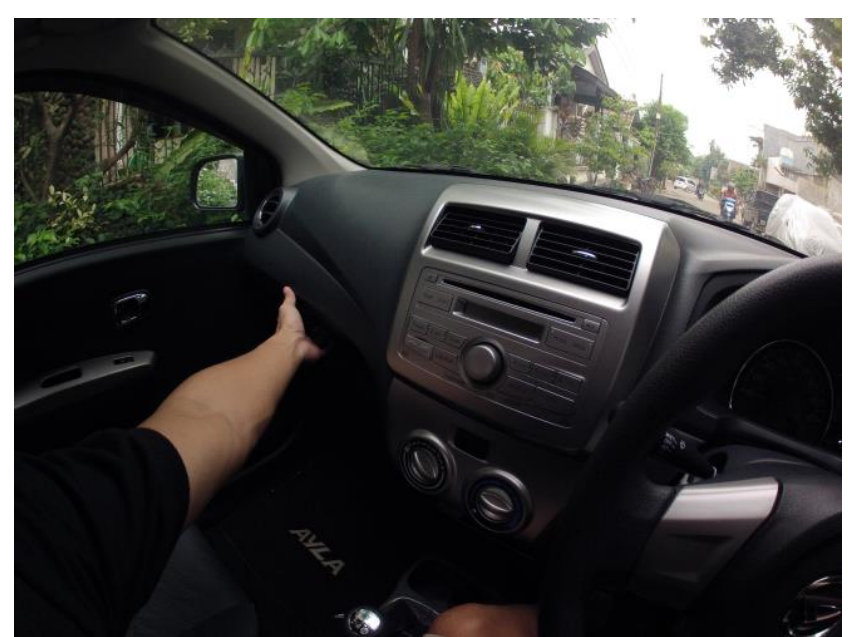

Gambar 17 posisi glove box Daihatsu Ayla (dukumentasi pribadi Hapiz)

Pada gambar 17 dapat dilihat bahwa akses kepada Glove Box pada Daihatsu Ayla mudah dijangkau oleh pengemudi, hal ini cukup mempermudah ketika melakukan kegiatan seorang diri dalam kendaraan, secara umum handel Glove box mudah dioprasionalkan. 

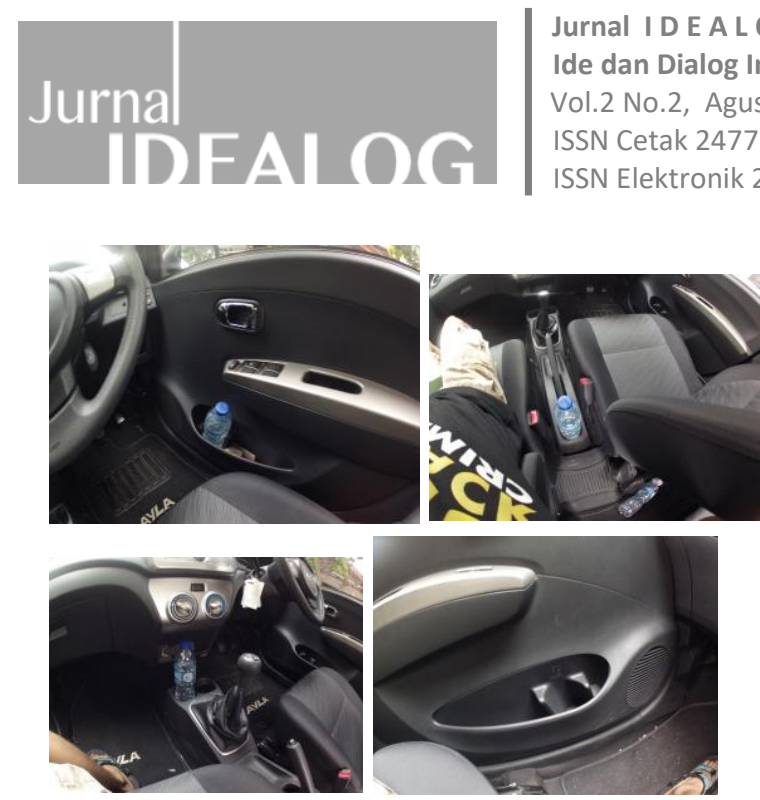

gambar 18 posisi cup holder / bottle holder Daihatsu Ayla (dokumentasi Pribadi Hapiz)

Pada gambar 18 posisi cup holder/bottle holder terdapat pada ke empat sisi pintu kendaraan dan di tambah di tengah console, cukup membantu pengguna baik pengemudi dan penumpang. Desain yang cukup baik memanfaatkan ruang pada interior yang terbatas tanpa mengurangi ergonomi penumpang dan pengemudi.

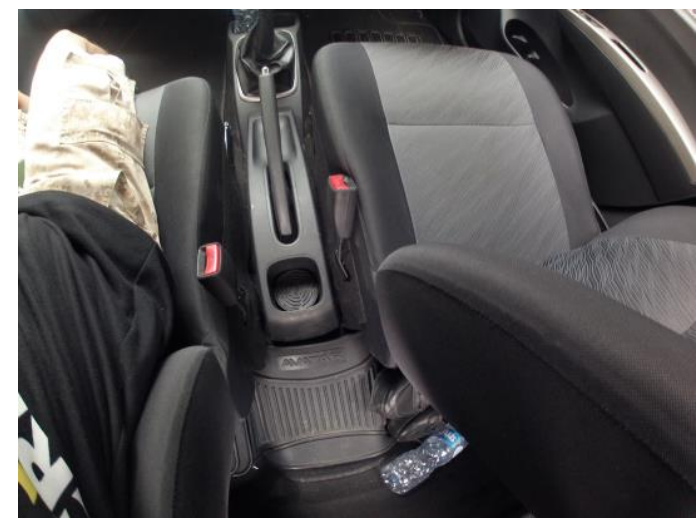

gambar 19 center console Daihatsu Ayla (dokumentasi pribadi Hapiz)

Gambar 19 menjelaskan posisi konsol tengah pada Daihatsu Ayla dapat di lihat bahwa posisi konsol tengah ada di tengah dengan desain yang sederhana tetapi cukup efektif karena terdapat 3 tempat botol atau cup holder pada konsol tengah dan bagian belakang dari konsol tengah dapat di gunakan sebagai tempat koin atau pun benda kecil lainnya dan sangat membantu, posisi tidak menyulitkan pengguna.

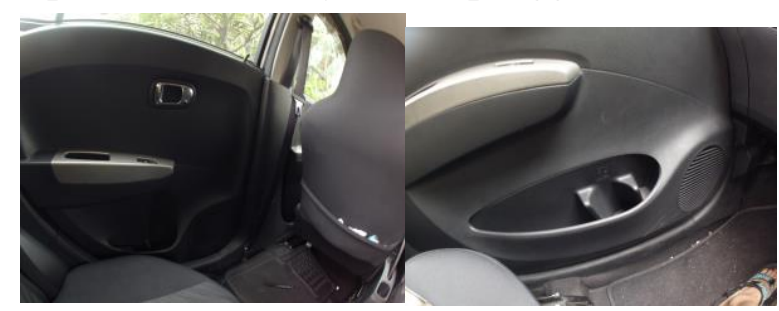

Gambar 20 side pocket Daihatsu Ayla ( dokumentasi pribadi)

Side poket pada Daihatsu Ayla ada pada ke empat sisi pintu kendaraan akan tetapi fungsi utama dari side pocket ini lebih dititik beratkan kepada penggunaan cup holder atau tempat botol air minum dan fungsi kedua adalah sebagai tempat buku atau barang lainnya, yang dapat masuk antara lain, payung lipat, tisu dan benda kecil yang berukuran 


\section{$10-20 \mathrm{~cm}$.}

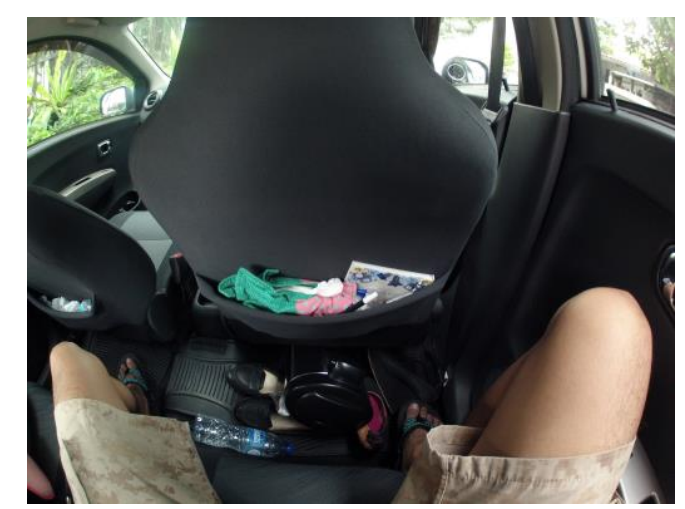

Gambar 21 seat back pocket Daihatsu Ayla (dokumentasi pribadi Hapiz)

Daihatsu Ayla juga dilengkapi seat back poket yaitu berguna untuk menaruh barang seperti majalah, buku atau Koran, posisi yang berada di jok depan sehingga yang mudah mengakses fitur ini adalah penumpang belakang, akan tetapi pengemudi juga mudah mengambil barang ditempat ini yang posisi di sebelah kiri atau tempat duduk penumpang, tidak ada kesulitan sama sekali ketika mengakses membuat fitur ini sangat berguna.

\section{Suzuki Karimun Wagon R}

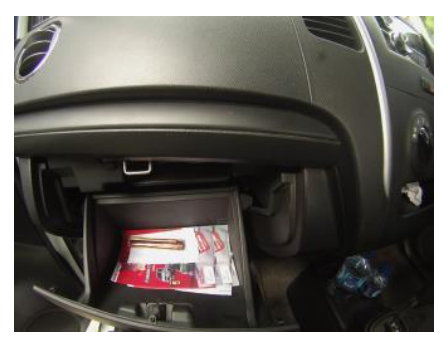

Gambar 22 glove box Suzuki Karimun Wagon R

( dokumentasi pribadi Hapiz)

gambar 22 menunjukan posisi glove box Suzuki Karimun Wagon R terletak di depan jok penumpang akses pada glove box ini cukup mudah baik untuk pengguna maupun pengemudi.

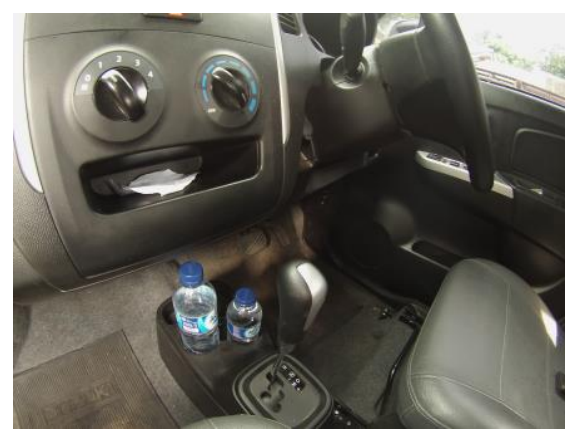

Gambar 23 cup holder/ bottle holder Suzuki Karimun Wagon R (dokumentasi pribadi Hapiz)

Suzuki Karimun Wagon R memiliki tempat untuk wadah botol jumlahnya ada dua dan diletakan di konsol tengah dari hasil pengujian jumlah cup holder cukup minim tidak dapat mengakomodir kebutuhan penumpang. 

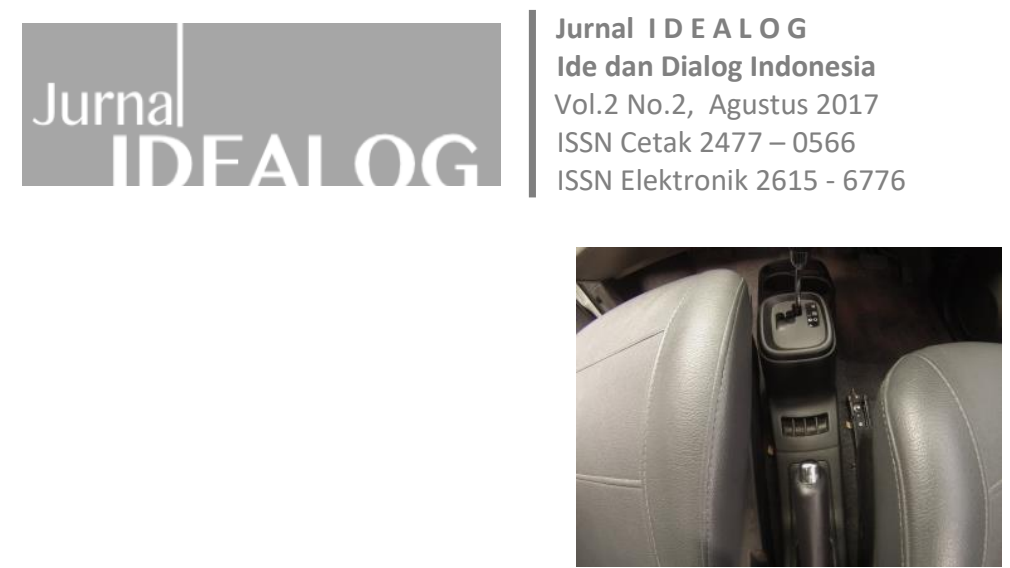

Gambar 24 center consol Suzuki Karimun Wagon R (dokumentasi pribadi Hapiz)

Gambar 24 menunjukan bahwa posisi konsol tengah Suzuki Karimun Wagon R cukup sederhana pada konsol tengah terdapat tempat koin, cup holder dan tray serbaguna akan tetapi penempatan tray yang terdapat didepan cup holder sangat kurang tepat gambar 24 karena ketika di simulasikan penempatan tray tersebut terhalang oleh botol mimunan atau benda lainnya.

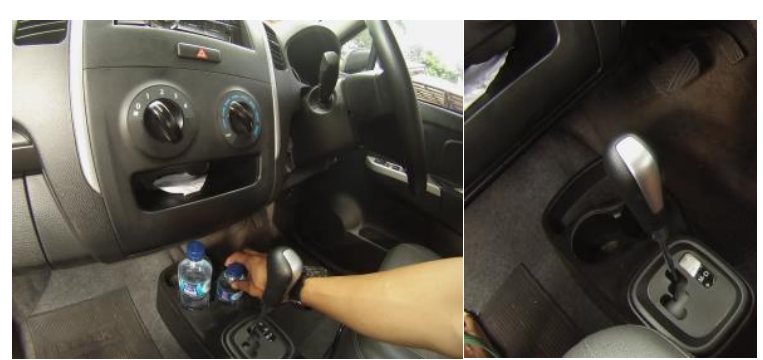

Gambar 25 posisi tray yang terhalang botol (dokumentasi pribadi Hapiz)

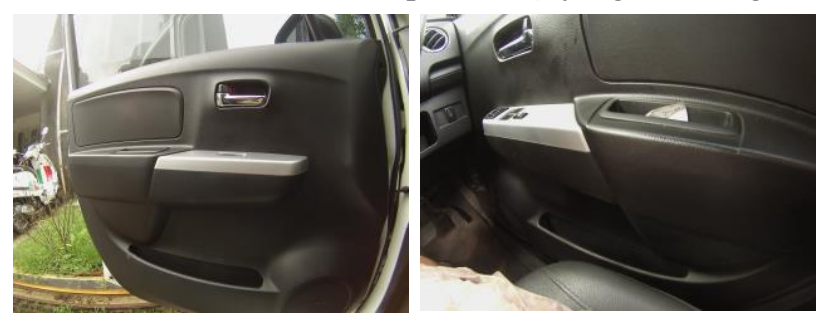

Gambar 26 side pocket Suzuki Karimun Wagon R (dokumentasi pribadi Hapiz)

side pocket pada Suzuki Karimun Wagon R terletak pada ke empat sisi pintu kendaraan namun pad wagon $\mathrm{R}$ side pocket hanya berfungsi sebagai tempat manaruh majalah, koran atau pun bendan yang berbentuk pipih, tidak dapat manaruh benda yang mempunyai ketebalan, dari hasil simulasi pada fungsi ini penumpang kesulitan meletakan botol minum.

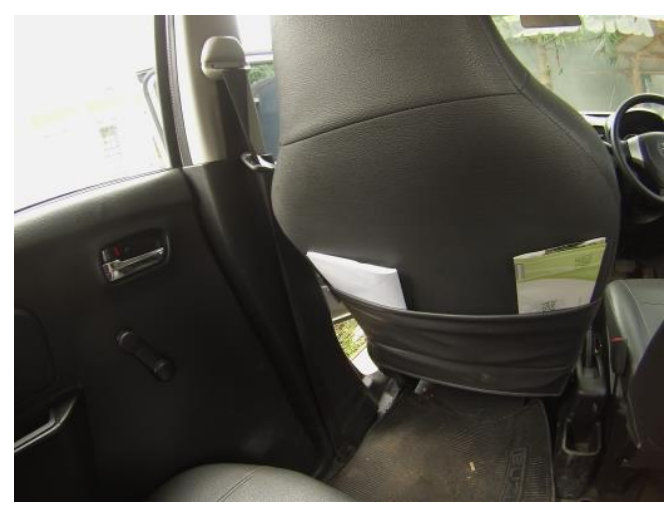

Gambar 27 seat back pocket Suzuki Karimun Wagon R (dokumentasi pribadi Hapiz) 
pada Suzuki Karimun Wagon R juga memliki seat back pocket yang berfungsi sebagai tempat untuk menaruh barang seperti Koran, buku dan benda lain yang kecil dan pipih. Namun kapasitas lebih kecil dari Daihatsu Ayla.

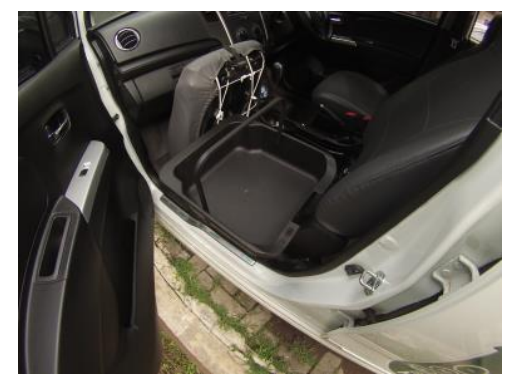

Gambar 28 secret tray/box Suzuki Karimun Wagon R (dokumentasi pribadi Hapiz)

Suzuki Karimun Wagon $\mathrm{R}$ dilengkapi dengan secret box yang cukup besar dengan dimensi 40x40 $\mathrm{cm}$ yang di letakan di bawah jok penumpang depan, secret box ini sangat berguna ketika membawa barang berharga kedalam mobil namun ketika disimulasikan pengguaanya cukup meyulitkan bila ada penumpang yang duduk di jok depan, karena penumpang harus turun dari jok tersebut baru dapat dioprasikan.

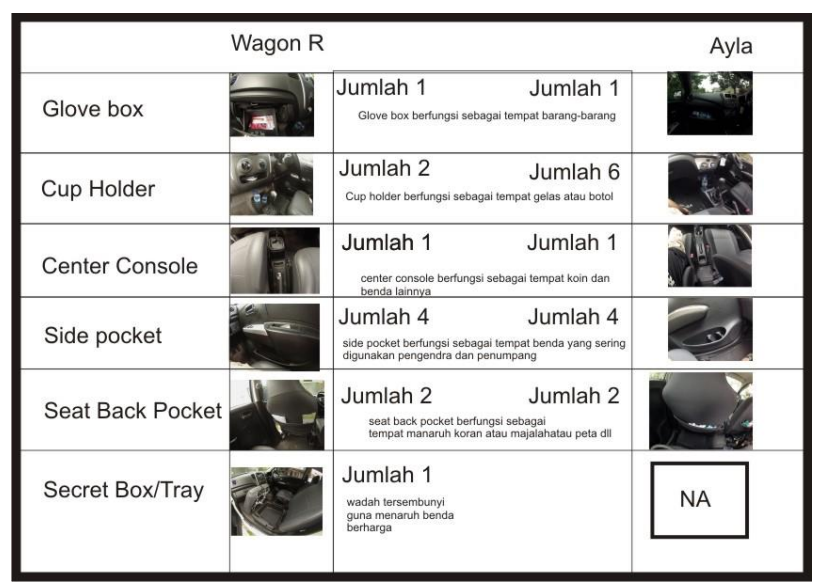

Gambar 29 fitur dan kelengkapan pada kedua interior kendaraan Suzuki Karimun Wagon R kiri Daihatsu Ayla kanan (dokumentasi pribadi Hapiz)

Dari hasil simulasi dan penelitan bahwa kelengkapan fitur dan fasiltas pada Suzuki karimun Wagon R mempunyai kekurangan yaitu kelengkapan jumlah cup holder atau tempat botol dari simulasi yang di peragakan bahwa kendaraan city car sangat membutuhkan cup holder dimana pengemudi dan pemumpang sering membawa botol air minum ketika dalam kendaraan, jumlah cup holder yang ada pada Daihatsu Ayla dirasakan cukup mengakomodir penumpang dan pengemudi karena mempermudah akses dalam penempatan dan pengambilan botol minum, selain itu side pocket yang di miliki oleh Daihatsu Ayla lebih unggul karena selain mampu menaruh botol minum juga dapat menaruh benda kecil lainnya bahkan dapat masuk payung lipat. Segi kelangkapan yang banyak tidak meyulitkan

pengguna bahkan sangat membantu didalam kendaraan sehingga membuat tingkat kenyamanan bertambah, desain interior Daihatsu Ayla yang berbasis sedan city car ini tidak membatasi ruang gerak kabin masih terasa luas walau diisi oleh 4 pemumpang dewasa, Suzuki Karimun Wagon R memang berbasis MPV city car dengan konsep MPV yang mampu membawa barang lebih banyak, hal ini didapat dari langit-langit yang cukup tinggi dari jarak kepala, namun hal tersebut tidak banyak membantu dari segi 
kenyamanan, faktor kenyamanan menjadi faktor utama dalam berkendara.

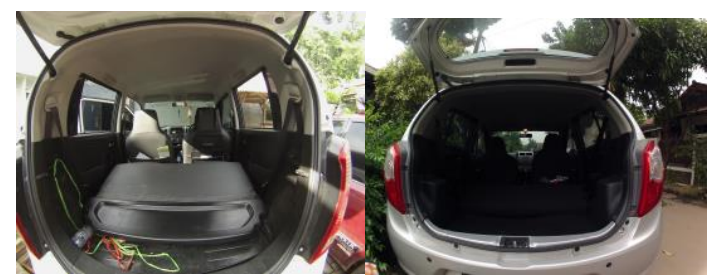

Gambar 30 jarak tinggi langit-langit,kiri Suzuki Karimun Wagon R, kanan Daihatsu Ayla (dokumentasi pribadi Hapiz)
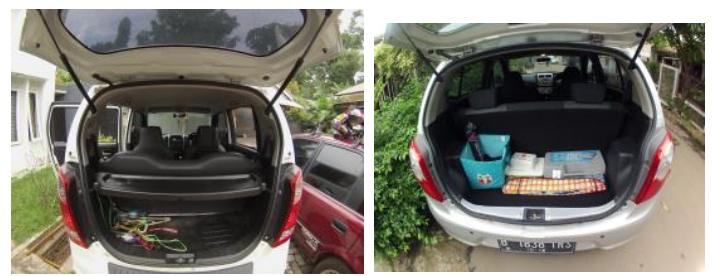

Gambar 31 luasan dari bagasi, kiri Suzuki KArimun Wagon R, Kanan Daihatsu Ayla (dokumentasi pribadi Hapiz)

Gambar 31 menjelaskan luasan bagasi dari masing-masing kendaraan Suzuki Karimun Wagon R memiliki ruang lebih tinggi sehingga kapasitas bagasi lebih besar namun untuk membawa barang yang lebih banyak harus melepas tray bagian tengah sehingga menambah beban kerja dan tray tersebut harus di letakan di tempat lain, berbeda halnya pada Daihatsu kebutuhan bagasi sangat cukup dan mudah.

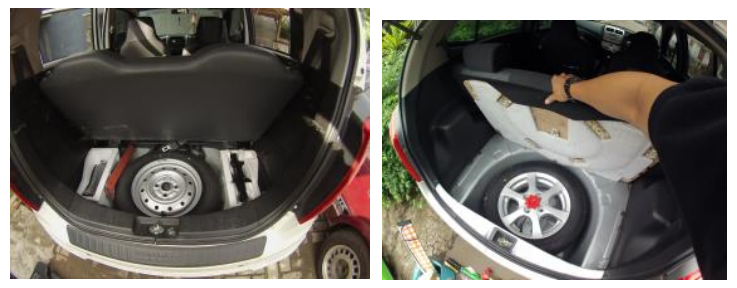

Gambar 32 posisi ban cadangan dan peralatan darurat, kiri Suzuki Karimun Wagon R, kanan Daihatsu Ayla (dokumentasi Pribadi Hapiz)

Gambar 32 adalah menunjukan posisi ban cadangan dan peralatan darurat seperti dongkrak dan panel segi tiga pengaman, pada Suzuki Karimun Wagon R peletakan sejajar sehingga memudahkan pengambilan peralatan, sedangkan pada Daihatsu Ayla peletakan peralatan ada dibawah ban cadangan sehingga harus mengangkat ban cadangan terlebih dahulu, akan tetapi desain tersebut dapat memecahkan efektifitas ruang dengan menaruh dibawah ban cadangan.
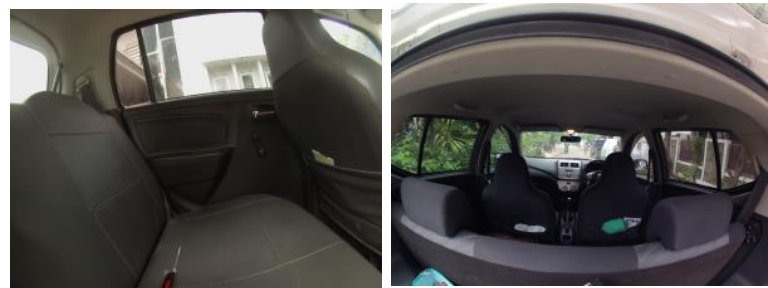

Gambar 33 sandaran jok penumpang kiri Suzuki Karimun Wagon R, kanan Daihatsu Ayla (dokumentasi pribadi Hapiz) 
Sandaran Jok penumpang gambar 33 pada Suzuki Karimun Wagon R tidak dapat diatur ketinggiannya sedangkan pada Daihatsu Ayla dapat diatur ketinggiannya, hal ini berdampak pada faktor keamanan penumpang.

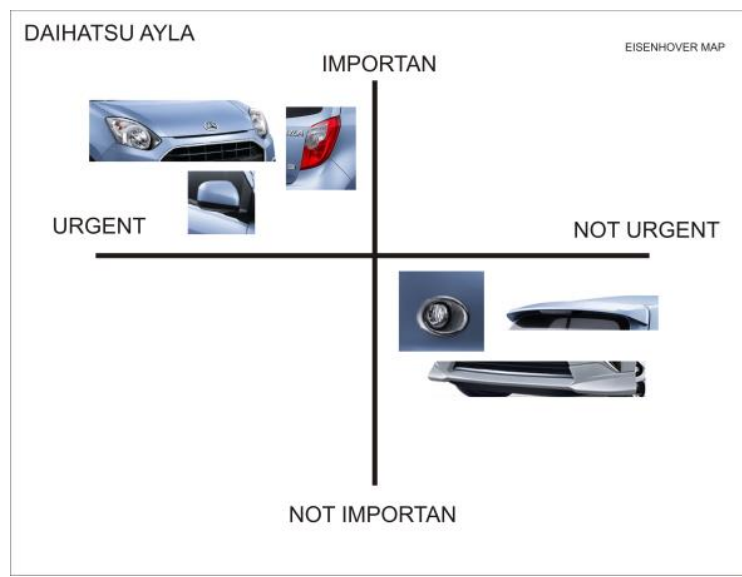

Gambar 34 posisioning styling eksterior Daihatsu Ayla

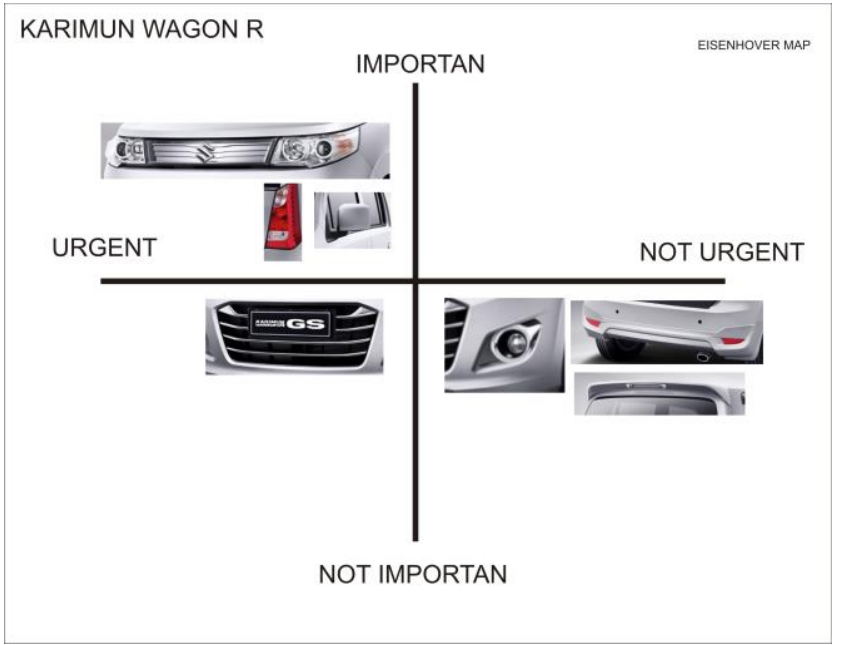

Gambar 35 Posisioning styling eksterior Suzuki Karimun Wagon R

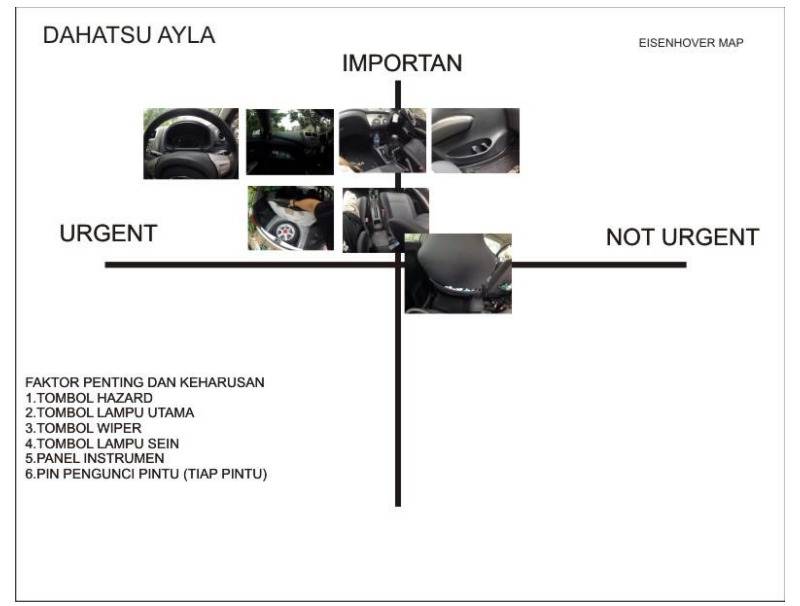

Gambar 36 posisioning fitur interior Daihatsu Ayla 


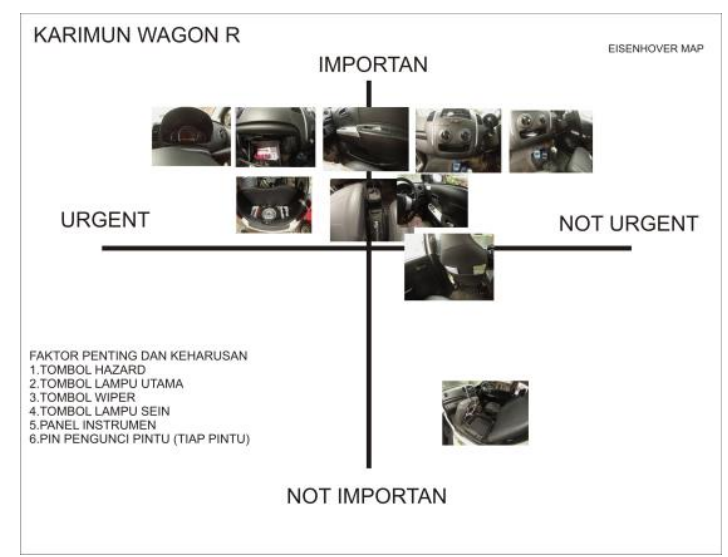

Gambar 37 Posisioning fitur interior Suzuki Karimun Wagon R

Bersadarkan data diatas maka dapat disimpulkan bahwa kebutuhan pengguna dalam kendaraan harus dipenuhi dan disesuaikan dengan jenis kendaraan tersebut, banyaknya fitur yang mempermudah penggunaan maka akan meningkatkan keamanan dan kenyamanan, sehinnga banyaknya fitur bukan dikarenakan pemuas semata tetapi memang berdasarkan kebutuhan akan tetapi dalan desain interior Suzuki karimun banyak mengorbankan sisi styling dilihat dari banyaknya kebutuhan basic yang seharusnya dapat di redesign dengan mendesain lebih baik melalui terasformasi bentuk apalagi secara dimensional ruang kabin Suzuki karimun wagon $\mathrm{R}$ di bagian langit-langit lebih luas, selain itu faktor harga Suzuki karimun yang lebih rendah maka proses produksi mengorbankan sisi styling pada interior dan perlu diingat bahwa kendaraan masuk kedalam mobil LCGC dimana kebutuhan dasar lebih diutamakan. Secara styling eksterior keduanya memiliki keunggulan dalam segi tampilan hasil pengumpilan data dapat disimpulkan sasaran kendaraan ini adalah masyarakat ekonomi menengah yang tinggal di kota urban Jakarta sehingga tampillan eksterior lebih menonjol dibandingkan tampilan interior dan posisi city car yang hanya digunakan untuk mobilitas dalam kota maka lama rata-rata berada didalam kedaraan adalah 2 jam diukur dari responden yang memiliki kedua kendaraan ini tinggal di daerah kota satelit Jakarta, seperti Tanggerang Selatan, Bogor, bekasi dan perbatasan kota Jakarta lainnya

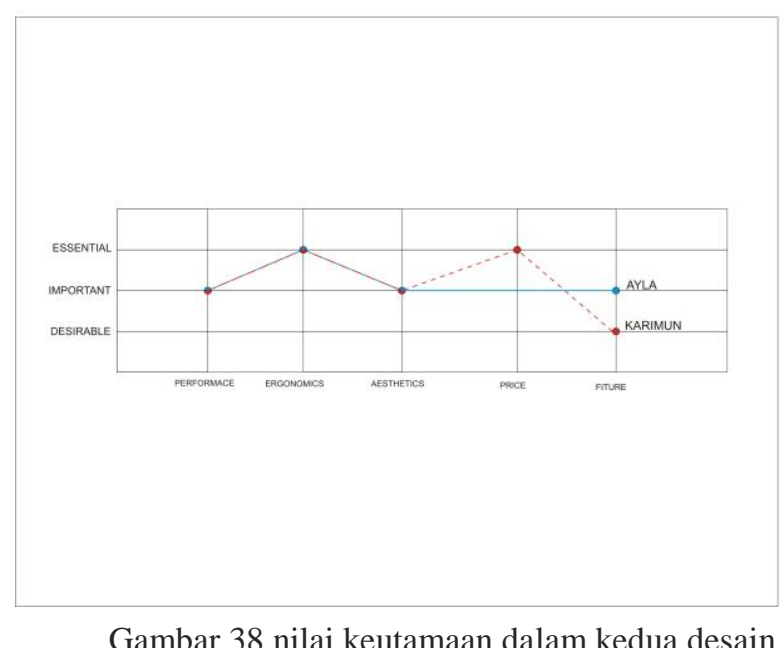

Gambar 38 nilai keutamaan dalam kedua desain 


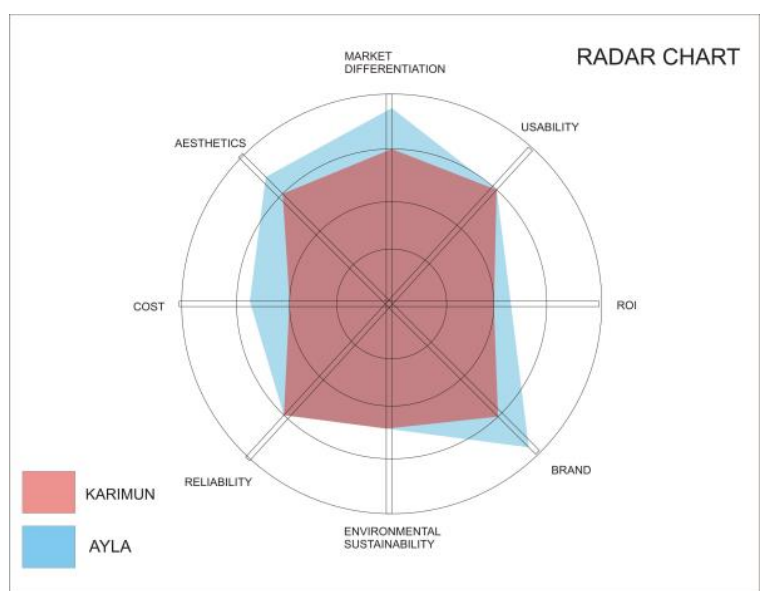

Gambar 39 Radar chart nilai pada keseluruhan kedua LCGC

Masyarakat urban kelas menengah di Jakarta umumnya para kelas pekerja, mereka menilai secara etnosentrisme, sehingga kebudayaan yang lebih tinggi atau kaum orang borjuis dipandang lebih baik dan tinggi sehingga life style mereka ditentukan oleh orang lain yang ia pandang lebih tinggi daripada yang lain contoh dalam penggunaan gadget justru paling banyak yang membelanjakan uangnya untuk kebutuhan ini adalah dari kelas masyarakat menengah dan dalam memilih kedaraan mereka cenderung memilih kedaraan yang dapat dicicil dengan murah dan secara styling kendaraan yang mereka dapat harus memiliki nilai potensial untuk di modifikasi baik secara tampilan interior dan eksterior sehingga mereka dapat naik kelas sosialnya, masyarakat kelas atas umumnya menyukai desain yang elegan, simpel dan sederhana mayarakat urban menengah mereka meniru pola ini akan tetapi dengan barang yang lebih murah
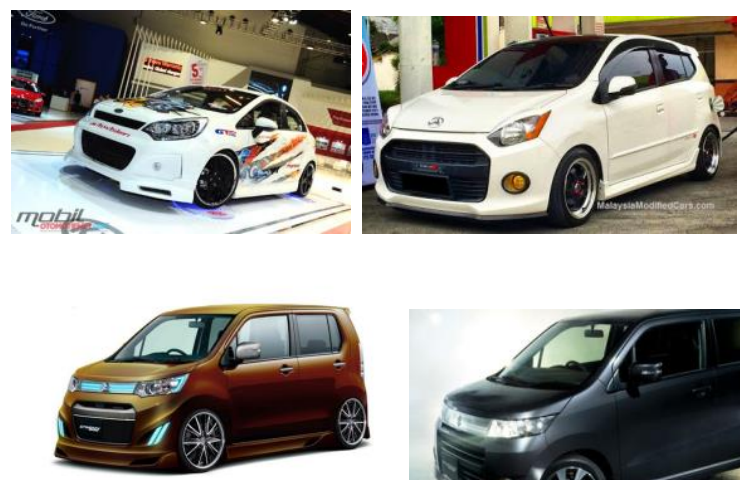

Gambar 40 modifikasi Daihatsu Ayla dan Suzuki Karimun wagon R (sumber pinterest diakses pada februari 2016)

Gambar diatas menunjukan bahwa peranan pabrikan atau sebuah desain sangat mempengaruhi kehidupan masyarakat urban dimana suatu kelas sosial masyarakat urban di Jakarta akan berusaha naik kelas sosial, oleh karena itu industri karesori dan industri assesoris di Indonesia cukup mempunyai celah untuk berkembang

\section{KESIMPULAN DAN SARAN}

\section{A. KESIMPULAN}


City car adalah kendaraan yang didesain untuk masyarakat urban diperkotaan yang tidak memiliki alat transpotasi umum yang kurang memadai oleh karena itu city car di Indonesia khususnya di Jakarta didesain guna memenuhi kebutuhan alat transpotasi, dengan lambatnya pembagunan fasilitas moda traspotasi umum di Jakarta para produsen kendaraan melihat celah pasar yang cukup besar pada masyarakat urban.

Masyarakat urban di Jakarta yang menggunakan mobil umumnya adalah golongan menengah, sehingga dalam golongan ini kebutuhan akan eksistensi diri sangat besar dan memiliki kendaraan adalah salah satu cara untuk mengangkat citra, dalam hal ini produsen menggunakan mobil LCGC utuk menjaring masyarakat menengah.

Kendaraan LCGC yang didesain oleh produsen kendaraan telah melalui tahapan yang cukup kompleks dan telah dilakukan pengujian, bila mana ada kesalahan hanya kesalahan minor yang dapat diperbaiki pada desain ditahun berikutnya sehinga akibat fatal dari desain hampir tidak ada.

Hal ini dikarenakan kemajuan teknologi untuk merekayasa sehingga tidak ada desain yang tidak dapat diproduksi, dalam penelitian ini menggunakan sampel dari dua merk LCGC yaitu Suzuki Karimun Wagon R dan Daihatsu Ayla, dari hasil penelitian di atas maka kedua desain kendaraan dalam bentuk styling bersifat subjektif dikarenakan faktor pengalaman yang berbeda terhadap kedua merk tersebut, faktor eronomi telah dipikir matang oleh pihak produsen sehingga hanya terdapat beberapa kesalahan kecil, dan konsep city car harus dipahami bahwa city car memang didesain untuk kendaraan dalam kota.

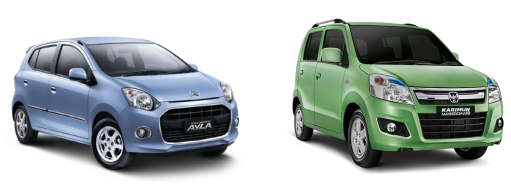

Gambar 41 Daihatsu Ayla dan Suzuki Karimun Wagon R (sumber Flicker dan pinters)

Perbedaan styling yang paling mencolok adalah jenis kendaraan Daihatsu Ayla menggunakan platform sedan dan Suzuki Karimun Wagon R menggunakan platform MPV.

Penggunaan material yang direduksi guna mengejar harga yang murah dapat didesain dengan baik karena kemajuan teknologi sehingga secara visual maupun secara teknis dapat menghasilkan nilai estetis yang cukup baik.

Dalam masyarakat urban dapat dikatakan bahwa citra dan status sosial sangat dijunjung tinggi terutama dalam kelas masyarakat menengah dikarenakan mereka membutuhkan status untuk tetap eksis dalam kehidupan bermasyarakat, sehingga keberadaan city car dalam jajaran LCGC maka mampu mengangkat status sosial mereka dengan memiliki salah satu dari kendaraan tersebut, dikarenakan mampu mengangkat status sosial maka para konsumen di kelas ini berlomba-lomba untuk memiliki city car sehingga budaya konsumerisme meningkat. Karena suatu status dalam mayarakat menjadi penting maka gaya hidup mereka pun ikut berubah mengikuti gaya yang lebih hedon.

Keberadaan city car kelas LCGC meningkatkan usaha pendukung otomotif misalnya assesoris, peran assesoris dapat mengangkat tampilan secara styling pada city car dan assesoris dapat memenuhi hasrat pemilik city car, sehingga city membuat perubahan pola gaya hidup pada masyarakat urban 


\section{B. SARAN}

Dengan adanya transfer teknologi dan pengetahuan material yang maju maka disarankan para desainer dan pemerintah mulai membuat desain karya dalam negri tanpa ketergantungan pihak asing, tidak hanya dalam bidang otomotif tetapi juga dalam bidang industri lainnya.

\section{DAFTAR PUSTAKA}

\section{Buku}

Colani, Luigi, "design of tomorrow" car styling 1979

Darsono Sony Kartika, Estetika, (Bandung: Rekayasa Sains Bandung, 2007),3

Emotional design, hal 48

H.Assael, customer behavior, 1984 hal 252

Kotler ,Philip dan Gary Armstrong.Op. Cit. hal 210.

Mowen, John, C., dan Minor, M., (2002), Perilaku Konsumen Jilid 1, Edisi Kelima (terjemahan), Erlangga, Jakarta

Nurmianto, E., (1991), "Ergonomi Konsep Dasar dan Aplikasinya”, Edisi Pertama, Institut Teknologi Sepuluh November, Penerbit Guna Widya, Surabaya.

Paul B. Horton \& C. Hunt, 1999,"sosiologi", erlangga, Jakarta

Raymon Loewy Industrial Design. Overlook books, reprint edition 2007, ISNB-10; 1585679850

Sutalaksana, Teknik tata cara kerja, itb,bandung,1979

Weimer, J. (1990), "Handbook of Ergonomic and Human Factors Tables", PTR Prentice Hall, Englewood Eliffs, New Jersey 07632.

Walter H. korff,1980, “ Designing tomorrows cars”, M-C Publications,Burbank, Calift 91506-1996.

\section{Website}

https://en.wikipedia.org/wiki/Kei_car

https://www.google.co.id

https:www.daihatsu.co.id

https:www.suzuki.co.id

https:flicker.com 
https:pinterest.com 